International Journal of Engineering \& Technology, $7(4.20)(2018) 602-607$
SPC
Website: www.sciencepubco.com/index.php/IJET
Research paper

\title{
Comparison of Nine Meteorological Drought Indices Over Middle Euphrates Region During Period from 1988 To 2017
}

\author{
Imzahim A. Alwan ${ }^{1 *}$, Abdul Razzak T. Ziboon', Alaa G. Khalaf ${ }^{3}$ \\ ${ }^{1,2}$ University of Technology, Civil Engineering Department, Iraq \\ ${ }^{3}$ Ministry of Science and Technology, Space and Communication Directorate, Iraq \\ *Corresponding author E-mail:40164@uotechnology.edu.iq
}

\begin{abstract}
The aim of this research is compare between nine drought indices and evaluate their performance with respect to predict and monitoring drought over Middle Euphrates region during period from 1988 to 2017.These indices are RDI, Normal SPI, Gamma SPI, Log SPI, CZI, MCZI, RAI, PN, and DI.Season and annual time scale were used to calculate all indices at Dewaniya, Hilla, Karbala, Najaf, and Semawa stations. The Pearson correlation coefficient between nine drought indices were analyzed. Annual and seasonal results illustrated that the maximum value of correlation between RDI and the other indices was noted with Gamma SPI and Log SPI at all stations. In annual time scale, the correlation coefficient reached to (0.99) at all stations except Hilla station, where it reached to (0.98), while in seasonal time scale the correlation coefficient reached to (0.98) at all stations. The RDI, Gamma SPI and Log SPI indices have similarity of classes and frequencies for drought. They also have similarity of frequencies for wet but there are minimum differences between wet classes compared to other indices. The RDI, Gamma SPI and Log SPI are good indices to predict and monitoring drought in study area in comparison to other indices which mentioned above.
\end{abstract}

Keywords: DI, Drought indices, Gamma SPI, Middle Euphrates Region, RDI

\section{Introduction}

Dry spell is ordinary wonder that results from proceeding with absences of rain over stretched out timeframe contrasted with some long haul typical conditions, prompting water needs for a few exercises or the natural division (Sanmartín et al, 2018). Dry season varies from other ordinary perils since dry season develops step by step, making it difficult to pinpoint the start and end of an event. On an exceptionally essential dimension a dry season is a deficiency in the typical open water in a given hydrological system (Barker et al, 2016). Breaking down precipitation information is one of the strategies to examine dry spell, which is considered as a standout amongst the most widely recognized techniques (Najjar and Ramandi, 2015). UNDP (2008) characterizes dry spell as wonder that happens normally when precipitation is underneath normally recorded dimensions, causing genuine hydrological disturbances that contrarily impact on Earth asset creation frameworks (Babu, 2016). Usage of dry season files is important for watching and anticipating dry season. Additionally, these files empower to assess dry spell peril. Albeit none of these files is better than another, some capacity superior to anything others improve the situation a few applications and hydro-atmosphere conditions. The dry season checking framework is affected by an exact decision of lists for dry spell location, giving target depiction of dry spell conditions. In this way, it is basic the appropriateness of various dry season lists be evaluated and the best record be chosen (Eshghabad et al, 2014). In this exploration, nine meteorological dry spell lists were utilized, to be specific the RDI List, Typical SPI list, Log SPI record, Gamma SPI list, CZI list, MCZI file, RAI list, PN List and DI file. All these files were connected for a similar arrangement of meteorological information 1988- 2017 and the fundamental time unit was season and yearly.

\section{Materials and Methods}

\subsection{Area of study}

The area of study is located in the Middle Euphrates Region. It is bounded by the coordinates (from $43^{\circ} 30^{\prime} \mathrm{E}$ to $45^{\circ} 30^{\prime} \mathrm{E}$ ) longitude and (from $31^{\circ} 0^{\prime} \mathrm{N}$ to $33^{\circ} 0^{\prime} \mathrm{N}$ ) latitude in zone $38 \mathrm{~N}$ according to UTM projected coordinate system. It covers an area of $26611 \mathrm{Km}^{2}$ (figure 1). The climate of study area is arid to semi-arid with dry hot in summer and cool in winter. Rainfall in the area begins in October and ends in May after which it becomes scarce.

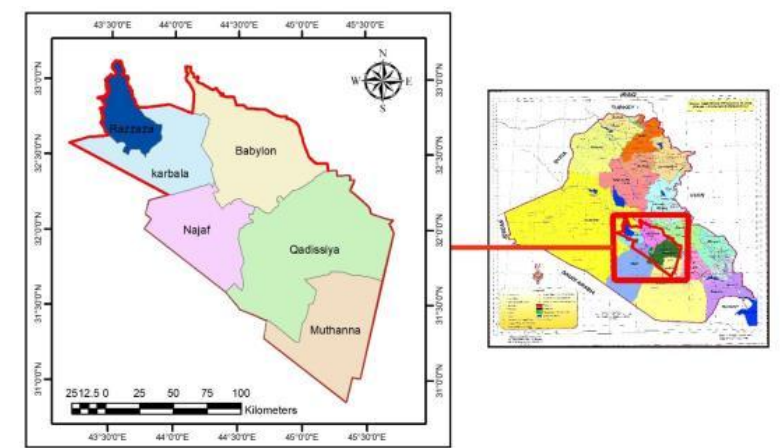

Fig. 1: Iraq map with a map represents the study area (Modified by authors based on Iraq administrative map scale 1:1000000, Ministry of water resources/General Directorate for Survey 2006) 


\subsection{Meteorological data}

In this research, average rainfall and average temperature data were used to compute the drought indices. Monthly average rainfall, and monthly average temperature data were obtained from Iraqi Meteorological Organization and Seismology (IMOAS). Thirty years from 1988 to 2017 of data were obtained from five gauge stations over the study area and these stations are as illustrate in Table 1.

Table 1: Gauge stations of study area with its details

\begin{tabular}{|c|c|c|c|c|}
\hline Gauge & Name & E (Degree) & N (Degree) & Gauge Type \\
\hline 1 & Dewaniya & 44.98 & 31.98 & Surface Station \\
\hline 2 & Hilla & 44.43 & 32.48 & Surface Station \\
\hline 3 & Karbala & 44.01 & 32.61 & Surface Station \\
\hline 4 & Najaf & 44.31 & 31.98 & Surface Station \\
\hline 5 & Semawa & 45.26 & 31.3 & Surface Station \\
\hline
\end{tabular}

\subsection{Meteorological drought indices}

In this research, nine drought indices were used, the details of these indices is described below:

\subsubsection{Standardized Precipitation Index (SPI)}

SPI is index for monitoring drought created by McKee et al. in 1993 using fitting a gamma distribution for station frequency distribution of rain total. McKee et al developed this index and computed it according to periods such as $3,6,12,24,36$ and 48 months .These periods reflect the effect of wetness and dryness on the availability of variate water resources. Short period precipitation anomalies effect soil wetness and long period precipitation anomalies reflect effect on water resources (Khan and Gadiwala, 2013). Positive values of this index indicate more than average precipitation and negative values indicate less than average precipitation. Data record length is prescribed to be no less than thirty years, because the classes of this index are fitted to this time and are also intercomparable with other locations of variety climates (Shahabfar and Eitzinger, 2013). Calculation of this index includes fitting a gamma probability function to given time series of precipitation, and this function is computed as follow (Kumar et al, 2016):

$G(x)=\frac{1}{\beta^{\alpha} \Gamma(\alpha)} x^{\alpha-1} e^{-x / \beta} \quad$ for $x, \alpha, \beta>$ zero

Where: $\alpha$ and $\beta$ are the shape parameters. $X$ is the precipitation amount in $\mathrm{mm}$ and $\Gamma(\alpha)$ is the Gamma function of $\alpha$.

$\Gamma \alpha=\int_{0}^{\natural} y^{\alpha-1} e^{-y} d y$

$\alpha$ and $\beta$ parameters are computed as follow:

$\alpha=\frac{1}{4 * A}\left(1+\sqrt{1+\frac{44}{3}}\right)$

$\beta=\frac{\bar{x}}{\alpha}$

$A=\ln (\bar{x})-\frac{\sum \ln (x)}{n}$

Where, $\bar{x}$ is average rainfall in mm of all data of same event, $\mathrm{n}$ is number of precipitation data. After calculating values of $\alpha, \beta$ and A, the cumulative probability of the observed precipitation for a given period can be computed as follow:

$G(x)=\frac{1}{\beta^{\alpha} \Gamma(\alpha)} \int_{0}^{x} x^{\alpha-1} e^{-\frac{x}{\beta}} d x$

$H(x)=Q+(1-Q) G x$
(Kumar et al, 2016):

$S P I=-\left(t-\frac{2.515517+0.802853 * t+0.010328 * t^{2}}{1+1.432788 * t+0.189369 * t^{2}+0.001308 * t^{3}}\right)$

If $0<\mathrm{H}(\mathrm{x})<=0.5$

When $t=\sqrt{\ln \left(\frac{1}{[H(x)]^{2}}\right)}$

$S P I=+\left(t-\frac{2.515517+0.802853 * t+0.010328 * t^{2}}{1+1.432788 * t+0.189369 * t^{2}+0.001308 * t^{3}}\right)$

If $0.5<\mathrm{H}(\mathrm{x})<=1$

When $t=\sqrt{\ln \left(\frac{1}{[1-H(x)]^{2}}\right)}$

(Yacoub and Tayfur, 2017).

$S P I=\frac{\ln (x i)-\mu}{\sigma}$

It may be sometimes more effective, at the arithmetic level, to standardize the data directly from a fitted natural distribution where possible. Normal SPI is calculated as follow:

$S P I=\frac{x i-\mu}{\sigma}$

Where, $\mathrm{x}$ is precipitation, $\mu$ and $\sigma$ are the average and standard deviation of precipitation, respectively. The categorization of drought based on three types of SPI which mentioned above are given in Table 2(Yacoub and Tayfur, 2017).

\subsubsection{Reconnaissance Drought Index (RDI)}

This index is depends on the proportion between two accumulated amounts of precipitation and potential evapotranspiration ET0.Utilization of ET0 in the detection of drought has been useful in development of this index. The first step to compute this index is compute $\alpha \mathrm{o}$ and then computed it.Where, $\alpha \mathrm{o}$ is computed as following.

$\alpha o^{i}=\frac{\sum_{j=1}^{12} R i j}{\sum_{j=1}^{12} E T 0 i j}$

Where: Rij and ET0ij are precipitation and potential evapotranspiration of the jth month of the ith year.

$\operatorname{RDIstk}^{i}=\frac{y_{k}^{i}-A\left(y^{k}\right)}{\sigma y^{k}}$

Where, yk is the $\ln \left(\alpha \mathrm{o}^{\mathrm{i}}\right), \mathrm{A}\left(\mathrm{y}^{\mathrm{k}}\right)$ is the average and $\sigma \mathrm{y}^{\mathrm{k}}$ is the standardized deviation. The classes of RDI index were classified as shown in table 2(Shah et al, 2013). In this research ETo was estimated using the Thornthwait method. The estimation of ETo is computed in according with Thornthwaite (1948) by the equation (Al-Enezy, 2012):

ETO $=16\left(\frac{D T}{360}\right)(10 \mathrm{tn} / \mathrm{J})^{k} \mathrm{~mm} / \mathrm{month}$

$J=\sum_{i=1}^{12} i$

$i=\lfloor t n / 5\rfloor^{1.514}$

$k=(675 \times 0.000000001) J^{3}-(771 \times 0.0000001) J^{2}+$ $(179 \times 0.0001) J+0.492$

Where:

$E T O=$ Potential evapotranspiration for each month $(\mathrm{mm} / \mathrm{month})$ $t=$ Mean monthly temperature $\left(\mathrm{C}^{\circ}\right)$ 
$n=$ Number of month measurement

$J=$ Annual heat index $\left(\mathrm{C}^{\circ}\right)$

$i=$ monthly temperature parameter $\left(\mathrm{C}^{\circ}\right)$

$D$ : Number of the days a month.

$T$ : Average number of sunshine hours

\subsubsection{China-Z index (CZI), modified CZI (MCZI)}

The CZI is based on the Wilson Hilferty cube root conversion. The index is calculated as:

$C Z I i=\frac{6}{C}\left(\frac{C}{2} Q i+1\right)^{1 / 3}-\frac{6}{C}+\frac{C}{6}$

$C=\frac{\sum_{i=1}^{n}(X i-\bar{x})^{3}}{n * \sigma^{3}}$

$Q i=\frac{(x i-\bar{x})}{\sigma}$

Where $i$ is the current month, $\mathrm{C}$ is skewness coefficient, $\mathrm{n}$ is the total number data, $\mathrm{Q} i$ is standard variate, $\mathrm{x} i$ is rainfall of $i$ month, and $\overline{\boldsymbol{x}}$ is average of precipitation. To calculate the MCZI, the median of precipitation is utilized rather than the mean of precipitation in the calculation of the CZI (Morid et al, 2006). The classes of CZI and MCZI indices were classified as shown in table 2(Soleimani et al, 2013).

\subsubsection{Rainfall anomaly index (RAI)}

This index was presented by Van Rooy (1965). It depends on the computation of the rainfall in comparison to accidental numbers from -3 to +3 . In this index, the data is arranged in ascending manner from the highest to the lowest value, then by computing the mean of the ten highest and the ten lowest values of rainfall during the statistical period, the drought is computed according to the following equations:

$$
\begin{array}{ll}
R A I=\frac{(R-\bar{R})}{(M-\bar{R})} & \text { if } R>\bar{R} \\
R A I=\frac{(R-\bar{R})}{(X-\bar{R})} & \text { if } R<\bar{R}
\end{array}
$$

Where: $\mathrm{X}$ is the mean of the ten lowest values of rainfall, $\mathrm{M}$ is the mean of the ten highest values of rainfall, $\bar{R}$ is the long term mean rainfall, and $R$ is the rainfall value (Javan et al, 2016). The classes of this index are illustrated in Table 2(Sanmartín et al, 2018).

\subsubsection{Percent of Normal precipitation Index (PN)}

Alami et al, 2017 It is computed by the following relation:

$P N=\frac{P i}{\bar{P}} * 100$

Where: $\mathrm{P}$ is the normalized amount of precipitation of the current annual, $\bar{P}$ is the mean of rainfall in timeframe for each station (Mokarram and Mahmoodi, 2015). The PN values are classified as shown in Table 2 (Alami et al, 2017).

\subsubsection{Deciles Index (DI)}

This index, basically designed by Gibbs and Maher 1967. It depends on ranged rainfall data from biggest to littlest in long term record to build cumulative distribution and then this distribution is divided into ten deciles. Any rainfall value can be compared with these deciles. Equation for compute this index is:

$P i=\frac{i}{n+1} * 100$
Where, pi is probability of rain in number ith, $\mathrm{n}$ is number of rainfall data. Classes of this index are illustrated in Table 2(Nohegar et al, 2015).

The values range of RAI, PN, and DI are not similar to values range of SPI, RDI, CZI and MCZI indices. Therefore, rank values were used to make them comparable with the SPI, RDI, CZI and MCZI indices.

\section{Results and Discussion}

This research focused on comparison between known nine meteorological drought indices (RDI, Gamma SPI, Log SPI,Normal SPI,CZI, MCZI, RAI, PN, DI) over five stations of middle Euphrates region during period 1988 to 2017.These stations are Dewaniya,Hilla,Karbala,Najaf,and Semawa.

Middle Euphrates region is famous with agricultural, therefore seasonal and annual time scale were used to calculate drought indices which mentioned above. In seasonal time scale, only rainy seasons such as winter, spring, and autumn seasons were used to calculate all indices in all stations.

\begin{tabular}{|c|c|c|c|c|c|}
\hline Rank & $\begin{array}{c}\text { Drought } \\
\text { classes }\end{array}$ & $\begin{array}{c}\text { SPI,RDI,CZI, } \\
\text { And MCZI }\end{array}$ & RAI & $\mathrm{PN} \%$ & DI \% \\
\hline 3 & Extremely wet & $>=2$ & $>=3$ & $>=180$ & $>=90$ \\
\hline 2 & Severely wet & 1.5 to 1.99 & $\begin{array}{l}2 \text { to } \\
2.99\end{array}$ & $\begin{array}{c}161 \text { to } \\
180\end{array}$ & $\begin{array}{c}80 \text { to } \\
90\end{array}$ \\
\hline 1 & $\begin{array}{c}\text { Moderately } \\
\text { wet }\end{array}$ & 1 to 1.49 & $\begin{array}{l}1 \text { to } \\
1.99\end{array}$ & $\begin{array}{c}121 \text { to } \\
160\end{array}$ & $\begin{array}{l}70 \text { to } \\
80\end{array}$ \\
\hline 0 & Near normal & -0.99 to 0.99 & $\begin{array}{c}-0.99 \text { to } \\
0.99\end{array}$ & $\begin{array}{c}81 \text { to } \\
120\end{array}$ & $\begin{array}{c}30 \text { to } \\
70\end{array}$ \\
\hline-1 & $\begin{array}{c}\text { Moderately } \\
\text { drought }\end{array}$ & -1 to -1.49 & $\begin{array}{c}-1 \text { to }- \\
1.99 \\
\end{array}$ & 41 to 80 & $\begin{array}{c}20 \text { to } \\
30\end{array}$ \\
\hline-2 & $\begin{array}{c}\text { Severely } \\
\text { drought }\end{array}$ & -1.5 to -1.99 & $\begin{array}{l}-2 \text { to }- \\
2.99 \\
\end{array}$ & 21 to 40 & $\begin{array}{c}10 \text { to } \\
20\end{array}$ \\
\hline-3 & $\begin{array}{c}\text { Extremely } \\
\text { drought }\end{array}$ & $<=-2$ & $<=-3$ & $<=20$ & $<=10$ \\
\hline
\end{tabular}

Table 2: The categorization of drought indices

The Pearson's correlation coefficient matrix was used for the nine drought indices for each meteorological station. The RDI index was considered a reference for comparison with the other indices which mentioned above because it based on precipitation and potential evapotranspiration factor compared to other indices that relied on rainfall only. The annual and seasonal results illustrated that the maximum value of correlation between RDI index and the other indices was noted with Gamma SPI and Log SPI indices at all stations. In annual time scale, the correlation coefficient reached to (0.99) at all stations except Hilla station, where it reached to (0.98). However, in seasonal time scale the correlation coefficient reached to $(0.98)$ at all stations as shown in tables from 3 to 6.On the other hand, the RDI, Gamma SPI and Log SPI indices have similarity of classes and frequencies for drought and it have similarity of frequencies for wet but there are minimum differences between wet classes compared with the other indices. The RAI, PN, and DI indices have higher frequencies for drought and wet classes compared with the other indices as shown in figures from 2 to 21.This meaning the RDI, Gamma SPI and Log SPI were good indices to predict and monitoring drought in study area compared with the other indices which mentioned above. On other hand the results of RDI, Gamma SPI, and Log SPI illustrated that the study area was suffered from periods of drought during period 1988 to 2017 according to each station in it whether annual or seasonal as shown in figures from 2 to 17 . 


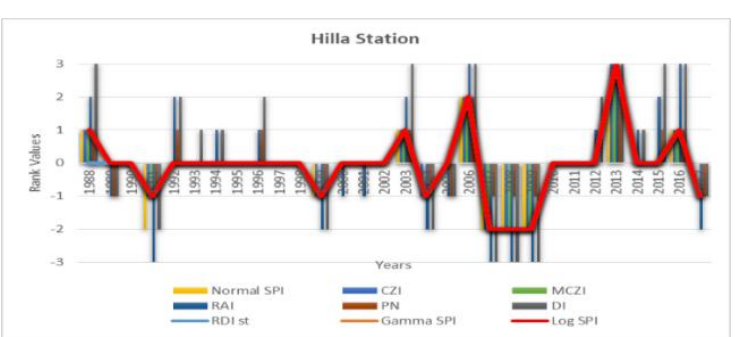

Fig. 2: Comparison graph for Dewaniya station

Table 3 The correlation coefficient between RDI index and the other indices (Annual time scale)

\begin{tabular}{|c|c|c|c|c|c|}
\hline Indices & $\begin{array}{c}\text { Dewaniya } \\
\text { Station }\end{array}$ & $\begin{array}{c}\text { Hilla } \\
\text { Station }\end{array}$ & $\begin{array}{c}\text { Karbala } \\
\text { Station }\end{array}$ & $\begin{array}{c}\text { Najaf } \\
\text { Station }\end{array}$ & $\begin{array}{c}\text { Semawa } \\
\text { Station }\end{array}$ \\
\hline Gamma SPI & 0.99 & 0.98 & 0.99 & 0.99 & 0.99 \\
\hline Log SPI & 0.99 & 0.98 & 0.99 & 0.99 & 0.99 \\
\hline Normal SPI & 0.91 & 0.92 & 0.96 & 0.98 & 0.98 \\
\hline CZI & 0.96 & 0.97 & 0.97 & 0.94 & 0.96 \\
\hline MCZI & 0.96 & 0.94 & 0.97 & 0.94 & 0.91 \\
\hline RAI & 0.84 & 0.85 & 0.85 & 0.83 & 0.82 \\
\hline PN & 0.89 & 0.83 & 0.90 & 0.86 & 0.81 \\
\hline DI & 0.71 & 0.81 & 0.83 & 0.83 & 0.80 \\
\hline
\end{tabular}

Table 4 The correlation coefficient between RDI index and the other indices (Winter time scale)

\begin{tabular}{|c|c|c|c|c|c|}
\hline Indices & $\begin{array}{c}\text { Dewaniya } \\
\text { Station }\end{array}$ & $\begin{array}{c}\text { Hilla } \\
\text { Station }\end{array}$ & $\begin{array}{c}\text { Karbala } \\
\text { Station }\end{array}$ & $\begin{array}{c}\text { Najaf } \\
\text { Station }\end{array}$ & $\begin{array}{c}\text { Semawa } \\
\text { Station }\end{array}$ \\
\hline Gamma SPI & 0.98 & 0.98 & 0.98 & 0.98 & 0.98 \\
\hline Log SPI & 0.98 & 0.98 & 0.98 & 0.98 & 0.98 \\
\hline Normal SPI & 0.97 & 0.93 & 0.94 & 0.96 & 0.97 \\
\hline CZI & 0.91 & 0.97 & 0.97 & 0.97 & 0.95 \\
\hline MCZI & 0.97 & 0.96 & 0.96 & 0.95 & 0.89 \\
\hline RAI & 0.66 & 0.74 & 0.78 & 0.67 & 0.70 \\
\hline PN & 0.80 & 0.81 & 0.87 & 0.85 & 0.75 \\
\hline DI & 0.65 & 0.70 & 0.78 & 0.65 & 0.59 \\
\hline
\end{tabular}

Table 5 The correlation coefficient between RDI index and the other indices (Spring time scale)

\begin{tabular}{|c|c|c|c|c|c|}
\hline Indices & $\begin{array}{c}\text { Dewaniya } \\
\text { Station }\end{array}$ & $\begin{array}{c}\text { Hilla } \\
\text { Station }\end{array}$ & $\begin{array}{c}\text { Karbala } \\
\text { Station }\end{array}$ & $\begin{array}{c}\text { Najaf } \\
\text { Station }\end{array}$ & $\begin{array}{c}\text { Semawa } \\
\text { Station }\end{array}$ \\
\hline Gamma SPI & 0.98 & 0.98 & 0.98 & 0.98 & 0.98 \\
\hline Log SPI & 0.98 & 0.98 & 0.98 & 0.98 & 0.98 \\
\hline Normal SPI & 0.95 & 0.87 & 0.80 & 0.94 & 0.96 \\
\hline CZI & 0.97 & 0.96 & 0.95 & 0.97 & 0.94 \\
\hline MCZI & 0.92 & 0.96 & 0.88 & 0.95 & 0.95 \\
\hline RAI & 0.83 & 0.85 & 0.84 & 0.77 & 0.78 \\
\hline PN & 0.87 & 0.83 & 0.84 & 0.83 & 0.78 \\
\hline DI & 0.78 & 0.80 & 0.76 & 0.74 & 0.68 \\
\hline
\end{tabular}

Table 6 The correlation coefficient between RDI index and the other indices (Autumn time scale)

\begin{tabular}{|c|c|c|c|c|c|}
\hline Indices & $\begin{array}{c}\text { Dewaniya } \\
\text { Station }\end{array}$ & $\begin{array}{c}\text { Hilla } \\
\text { Station }\end{array}$ & $\begin{array}{c}\text { Karbala } \\
\text { Station }\end{array}$ & $\begin{array}{c}\text { Najaf } \\
\text { Station }\end{array}$ & $\begin{array}{c}\text { Semawa } \\
\text { Station }\end{array}$ \\
\hline Gamma SPI & 0.98 & 0.98 & 0.98 & 0.98 & 0.98 \\
\hline Log SPI & 0.98 & 0.98 & 0.98 & 0.98 & 0.98 \\
\hline Normal SPI & 0.91 & 0.95 & 0.95 & 0.92 & 0.92 \\
\hline CZI & 0.96 & 0.88 & 0.93 & 0.95 & 0.97 \\
\hline MCZI & 0.90 & 0.83 & 0.93 & 0.95 & 0.89 \\
\hline RAI & 0.84 & 0.79 & 0.77 & 0.87 & 0.78 \\
\hline PN & 0.86 & 0.77 & 0.81 & 0.84 & 0.76 \\
\hline DI & 0.84 & 0.75 & 0.77 & 0.76 & 0.77 \\
\hline
\end{tabular}

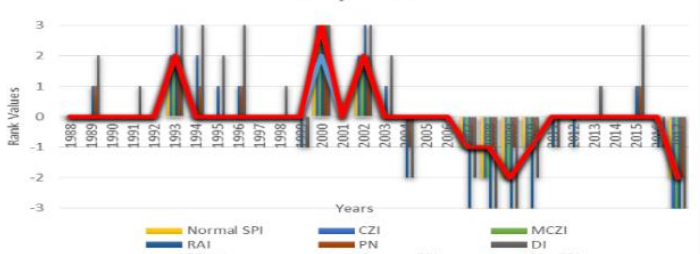

Fig. 3: Comparison graph for Dewaniya station (winter season)

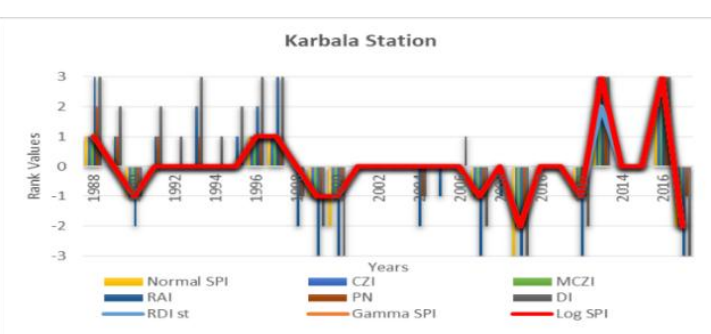

Fig. 3: Comparison graph for Hilla station

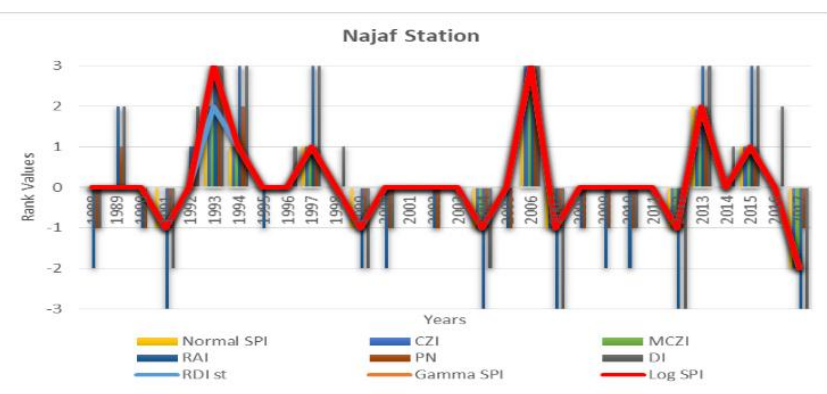

Fig. 4: Comparison graph for Karbala station

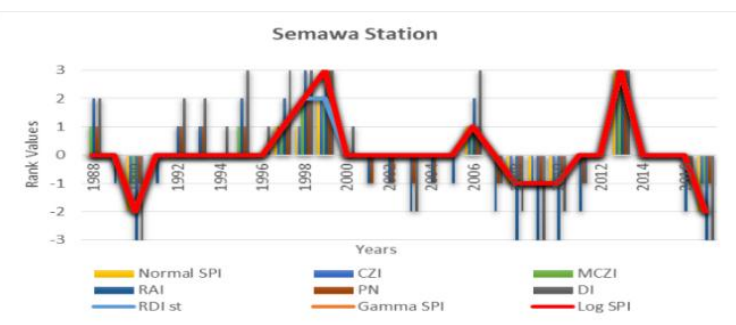

Fig. 5: Comparison graph for Najaf station

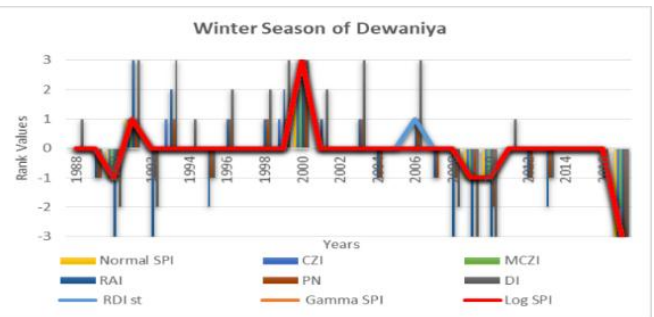

Fig. 6: Comparison graph for Semawa station

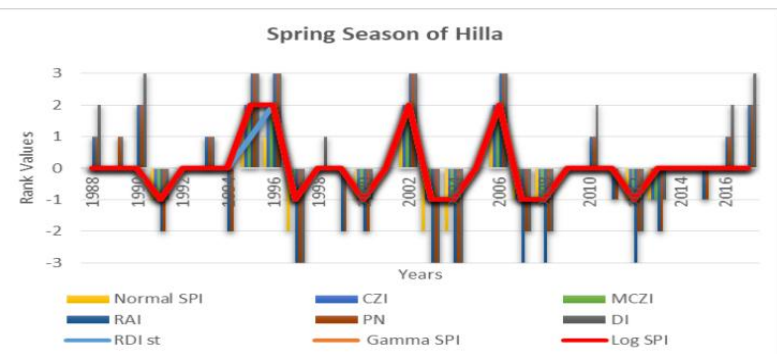

Fig. 7: Comparison graph for Dewaniya station (autumn season)

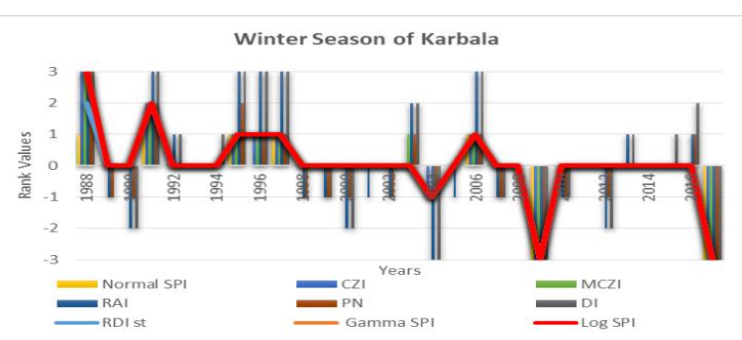

Fig. 8: Comparison graph for Hilla station (winter season) 


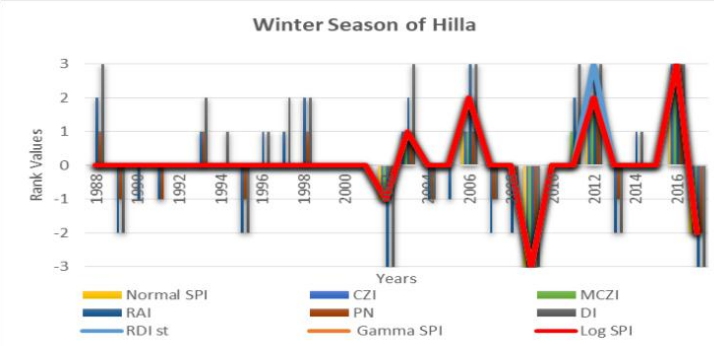

Fig. 8: Comparison graph for Dewaniya station (spring season)

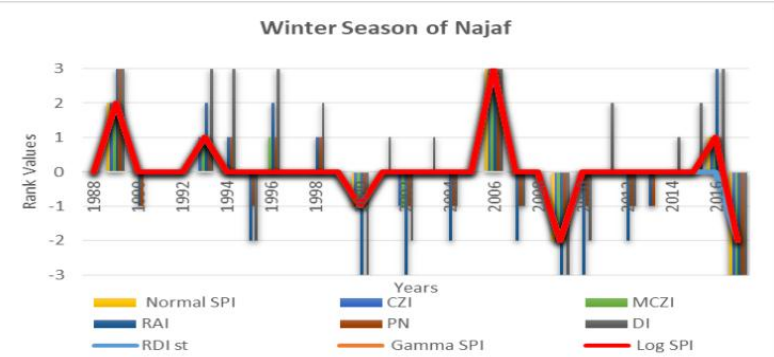

Fig.9: Comparison graph for Karbala station (winter season)

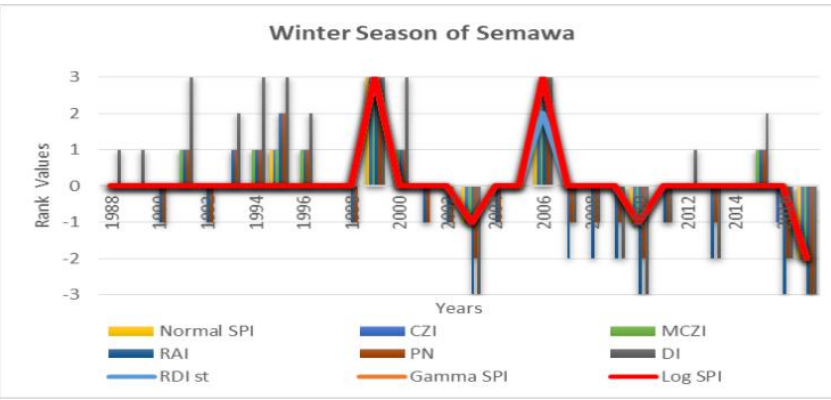

Fig. 10: Comparison graph for Najaf station (winter season)

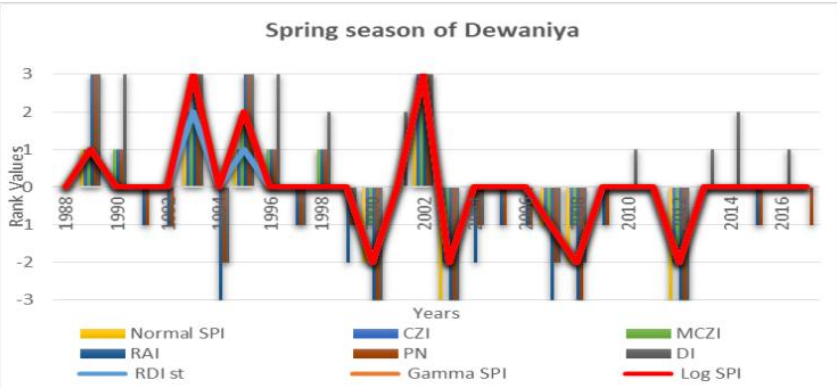

Fig.11: Comparison graph for Semawa station (winter season)

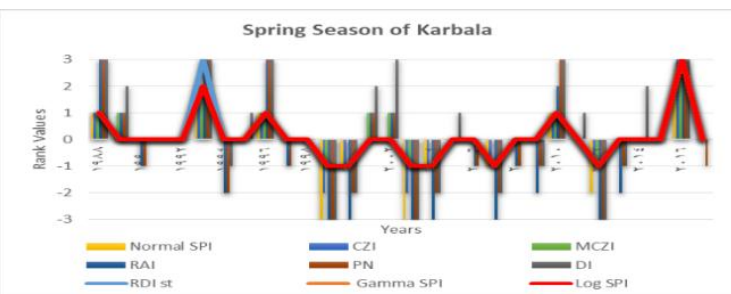

Fig.12: Comparison graph for Hilla station (spring season)

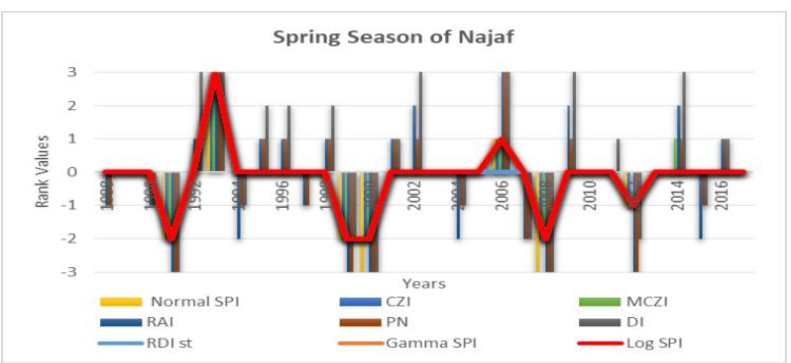

Fig. 13: Comparison graph for Karbala station (spring season)

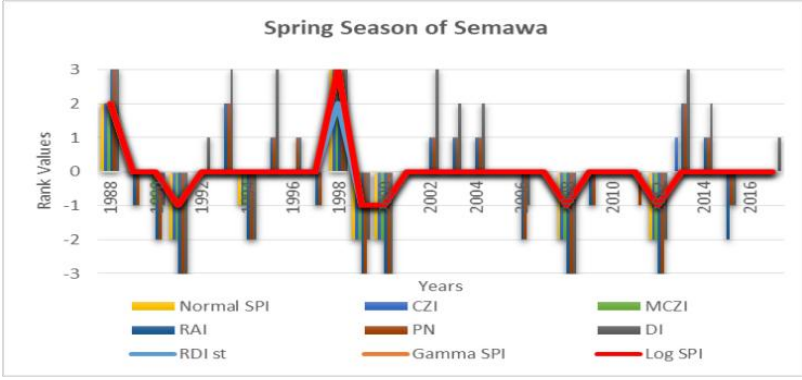

Fig.14: Comparison graph for Najaf station (spring season)

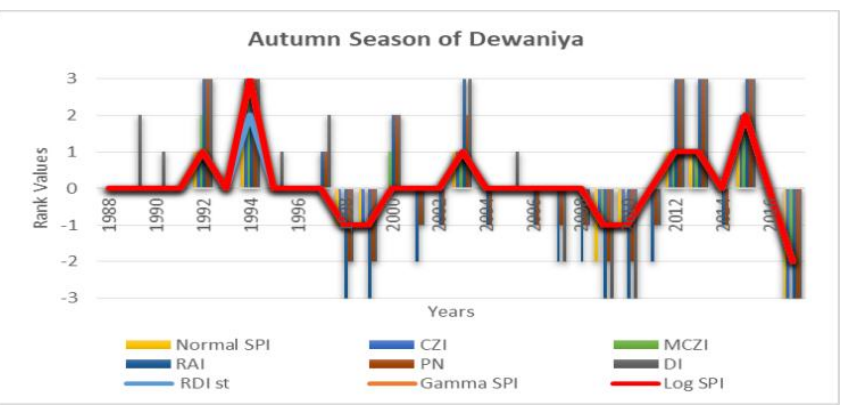

Fig. 15: Comparison graph for Semawa station (spring season)

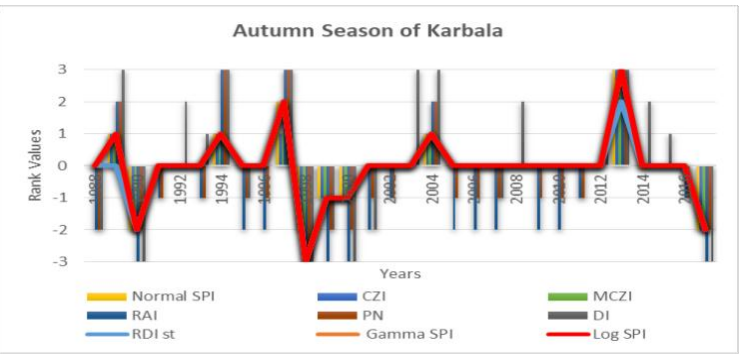

Fig. 16: Comparison graph for Hilla station (autumn season)

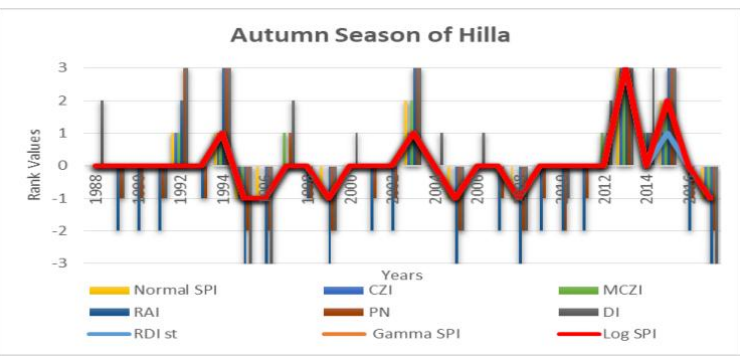

Fig.17: Comparison graph for Karbala station (autumn season)

\section{Conclusion}

1.Gamm SPI and Log SPI indices recorded high values of correlation with RDI index compared with the other indices.

2.The RDI, Gamma SPI and Log SPI indices have similarity of classes and frequencies for drought. They also have similarity of frequencies for wet but there are minimum differences between wet classes.

3.The RAI, PN, and DI indices have higher frequencies for drought and wet classes compared to other indices.

4.The RDI, Gamma SPI and Log SPI indices are good indices to predict and monitoring drought in study area.

5.Normal SPI, CZI, MCZI, RAI, PN, and DI indices are unsuitable to predict and monitoring drought in study area.

\section{References}

[1] Alami M M, Hayat E \& Tayfur G," Proposing a Popular Method for Meteorological Drought Monitoring in the Kabul River Basin, Afghanistan", International Journal of Advanced Engineering Research and Science (IJAERS), Vol.4, Issue 6,(2017),pp.103-110. 
[2] Al-Enezy A W, (2012)" Relationship between surface and shallow groundwater in the eastern side of shatt Al -Hilla, Iraq", MSc thesis, College of Science, University of Baghdad, Iraq.

[3] Babu C M," Critical Appraissal OF Meteorological Drought Indices: A Case Study on the Ananthapur District", International Journal of Advanced Research, Vol. 4, Issue 3, (2016), pp.17051717.

[4] Barker L J, Hannaford J, Chiverton A \& Svensson C," From Meteorological to Hydrological Drought Using Standardised Indicators", Hydrology and Earth System Sciences, Vol. 20, (2016), pp. 2483-2505.

[5] Eshghabad S M, Omidvar E \& Solaimani K," Efficiency of Some Meteorological Drought Indices in Different Time Scales (Case Study: Tajan Basin, Iran)", Ecopersia J. vol. 2, No 1, (2014), pp. 441-453.

[6] Javan K, Azizzadeh M R \& Yousefi S," An Investigation and Assessment of Meteorological Drought in Lake Urmia Basin Using Drought Indices and Probabilistic Methods", Natural Environment Change J., Vol. 2, No. 2, (2016),pp.153-164.

[7] Khan M A \& Gadiwala M S," A Study of Drought over Sindh (Pakistan) Using Standardized Precipitation Index (SPI) 1951 to 2010", Pakistan Journal of Meteorology, Vol. 9, Issue 18, (2013),pp.15-22

[8] Kumar R, Sagar A \& Bist A S," Assessment of Nagina Area of Distt. Bijnor U.P. on the Basis of Standard Precipitation Index (SPI) for drought Intensity", international journal of engineering sciences \& research Technology, Vol. 5, No.10, (2016), pp.18-26.

[9] Mokarram M \& Mahmoodi A R, (2015)" Using SPI and PN indices for determination of drought in the Fars Province", Journal of Applied Hydrology, Vol. 2, No. 1, (2015), pp.49-60.

[10] Morid S, Smakhtin V \& Moghaddasi M," Comparison of Seven Meteorological Indices for Drought Monitoring in Iran", International Journal of Climatology Vol. 26, (2006),pp.971-985.

[11] Najjar M S \& Ramandi R Y," Studying \& Comparing the Efficiency of 7 Meteorological Drought Indices in Droughts Risk Management (Case Study: North West Regions)", Applied Mathematics in Engineering, Management and Technology, Vol.3, No. 1, (2015), pp.131-142.

[12] Nohegar A, Mahmoodabadi S \& Norouzi A," Comparison the Suitability of SPI, PNI and DI Drought Index in Kahurestan Watershed (Hormozgan Province/South of Iran)", Journal of Environment and Earth Science, Vol.5, No.8,(2015),pp.71-77.

[13] Samaritan J F, Pan D, Fischer L, Orlowsky B, Hernández J G, Jordan F, Haemmig C, Zhang F \& Xu J," Searching for the Optimal Drought Index and Timescale Combination to Detect Drought: a Case Study from the Lower Jinsha River basin, China", Hydrology and Earth System Sciences, Vol. 22, (2018), pp.889-910.

[14] Shah R, Manekar V L, Christian R A \& Mistry N J,"Estimation of Reconnaissance Drought Index (RDI) for Bhavnagar District, Gujarat, India", International Journal of Environmental and Ecological Engineering, Vol.7, No.7,(2013),pp.507-510.

[15] Shahabfar A \& Eitzinger J," Spatio-Temporal Analysis of Droughts in Semi-Arid Regions by Using Meteorological Drought Indices", Atmosphere journal, Vol. 4, (2013), pp. 94-112.

[16] Soleimani H, Ahmadi H \& Zehtabian G,"Comparison of temporal and spatial trend of SPI, DI and CZI as important drought indices to map using IDW Method in Taleghan watershed", Annals of Biological Research, Vol. 4, No.6, (2013), pp.46-55.

[17] Yacoub E \& Tayfur G," Evaluation and Assessment of Meteorological Drought by Different Methods in Trarza Region, Mauritania", Water Resour Manage, Vol.31, (2017), pp.825-845. 